\title{
Correction to: Back to the Eneolithic: Exploring the Rudki type ornaments from Poland
}

\author{
Łukasz Kowalski ${ }^{1} \cdot$ Kamil Adamczak $^{1} \cdot$ Aldona Garbacz-Klempka ${ }^{2} \cdot$ Patrick Degryse $^{3,4} \cdot$ Zofia Stos-Gale $^{5}$. \\ Magdalena Kozicka ${ }^{1} \cdot$ Wojciech Chudziak ${ }^{1}$ - Andrzej Krzyszowski ${ }^{6} \cdot$ Artur Jedynak $^{7}$
}

Published online: 30 May 2019

(C) Springer-Verlag GmbH Germany, part of Springer Nature 2019

\section{Correction to: Archaeological and Anthropological Sciences https://doi.org/10.1007/s12520-019-00825-4}

In the original version of this paper, unintentionally, we have not acknowledged the contribution of our colleagues who provided the LIA database with the results obtained for the copper ores from Central and Western Europe. Therefore, the corrected caption of Figs. 4, 5, 6 and 7 should be:

The online version of the original article can be found at https://doi.org/ $10.1007 / \mathrm{s} 12520-019-00825-4$

Łukasz Kowalski

lukasz.k@doktorant.umk.pl

Kamil Adamczak

adamczak@umk.pl

Aldona Garbacz-Klempka

agarbacz@agh.edu.pl

Patrick Degryse

patrick.degryse@ees.kuleuven.be

Zofia Stos-Gale

zofia@stos-gale.com

Magdalena Kozicka

mkozicka@doktorant.umk.pl

Wojciech Chudziak

wojchud@umk.pl

Andrzej Krzyszowski

andrzej.krzyszowski@muzarp.poznan.pl
Artur Jedynak

artur.archeo@krzemionki.info

1 Institute of Archaeology, Nicolaus Copernicus University in Torun, Szosa Bydgoska 44/48, 87-100 Toruń, Poland

2 Faculty of Foundry Engineering, Historical Layers Research Centre, AGH University of Science and Technology, Reymonta 23, 30-059 Kraków, Poland

3 Earth and Environmental Sciences, Centre for Archaeological Sciences, KU Leuven, Celestijnenlaan 200E, b2408, 3001 Leuven, Belgium

4 Faculty of Archaeology Material Culture Studies Group, Leiden University, Leiden, The Netherlands

5 Ifold, UK

6 Archaeological Museum in Poznań, Wodna 27 - Pałac Górków, 61-781 Poznań, Poland

7 Archaeological Museum and Reserve "Krzemionki", Sudół 135a, 27-400 Ostrowiec Świętokrzyski, Poland 
Fig. 4 Comparisons of lead isotope ratios to the

nonradiogenic ${ }^{204} \mathrm{~Pb}$ of the DSOs found in Poland with the data for ores that contain minerals

marginally isotopically consistent with their lead isotope ratios.

Lead isotope database for Spanish ores includes about 1000 datasets, here only the copper ores that are known to be exploited in the Chalcolithic period are plotted. The lead isotope ratios for the DSOs plot between the groups of these deposits (Arribas and Tosdal 1994; Baron et al. 2006; Beck 2019; Brevart et al. 1982; Cattin et al. 2011; Gale et al. 1997; Hunt-Ortiz 2003; Klein et al. 2009; Le Guen and Lancelot 1989; Le Guen et al. 1991;

Marcoux and Brill 1986;

OXALID; Renzi et al. 2009;

Santos Zaldeuegui et al. 2004;

Sinclair et al. 1993; Stos-Gale et al. 1995; Tornos et al. 2004, adapted)
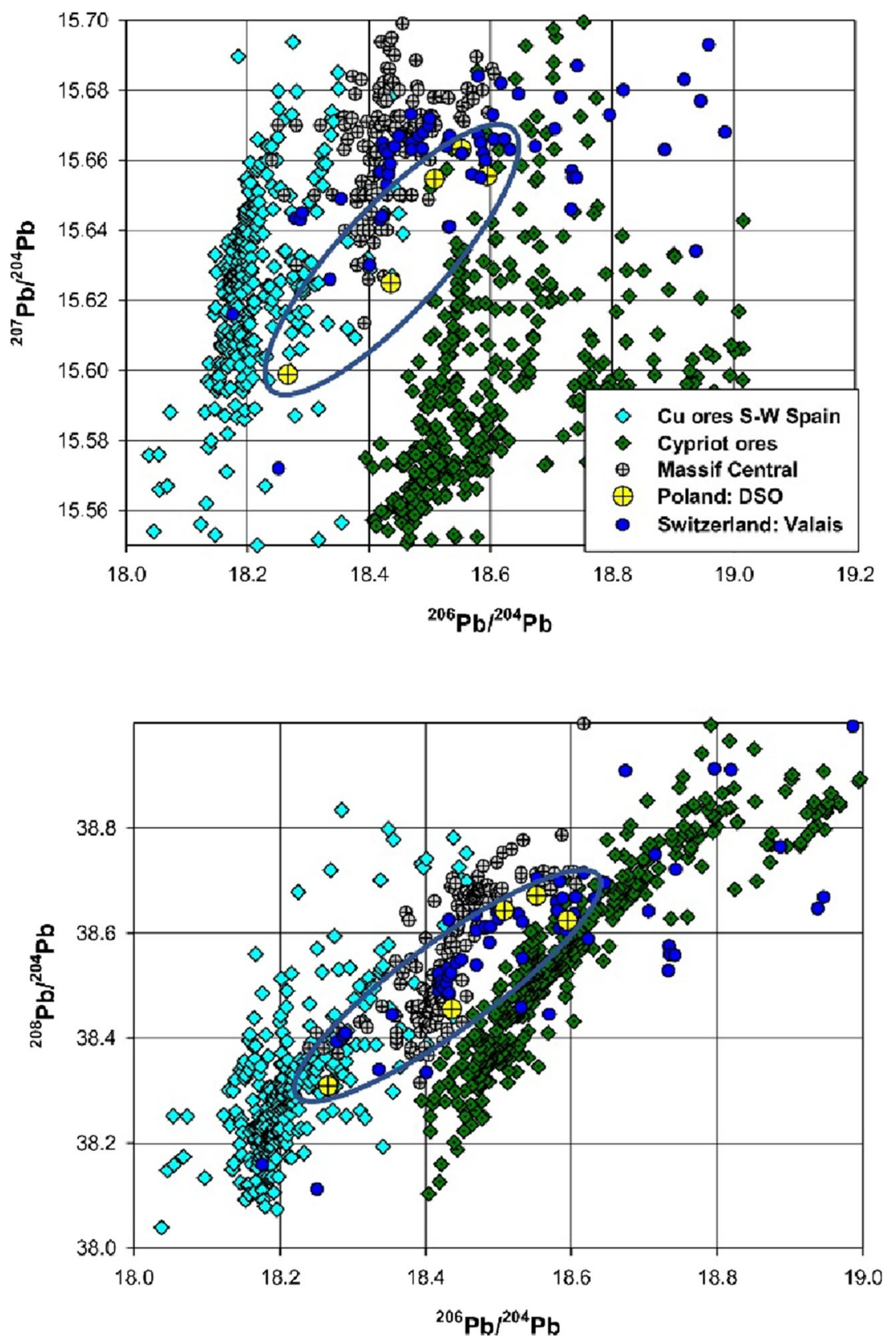
Fig. 5 Comparisons of lead isotope ratios to the radiogenic ${ }^{206} \mathrm{~Pb}$ of the analysed DSOs with the ores from the Slovak

Carpathians and the Harz

Mountains indicate that these ornaments have compositions consistent with the Slovak ore deposits in Špania Dolina and Banská Štiavnica. The upper plot clearly shows that the ores from Harz plot below the ores from Slovakia and the analysed DSOs (Andras et al. 2010; Bielicki and Tischendorf 1991; Chernyshev et al. 2007; Haak and Lévêque 1995; Niederschlag et al. 2003;

Schreiner 2007; Tischendorf et al. 1993, adapted)
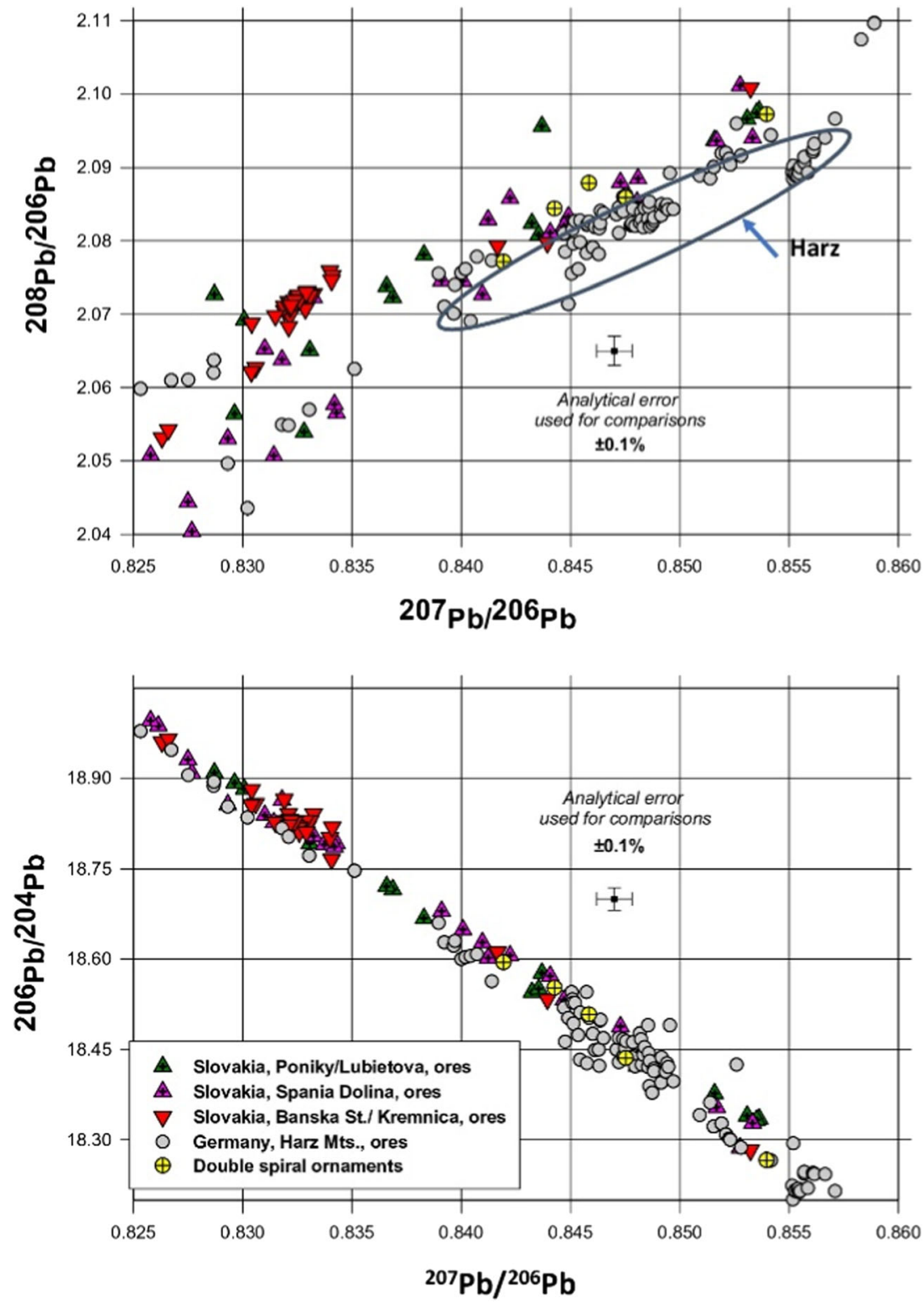
Fig. 6 Comparisons of lead isotope ratios of Neolithic/ Eneolithic copper artefacts from Slovakia and double spiral ornaments from Polish sites show clearly that majority of artefacts in both groups are consistent with the lead isotope characteristics of ores from the Slovak Ore

Mountains. In this plot, there are also included data for various ore samples from the region of

Salzburg which have lead isotope ratios similar to some of the ornaments. However, these ores have to be rejected as source of copper for these artefacts, because there are lead ores and Fahlores, therefore chemically not consistent with the DSOs (Köppel 1983; Köppel and Schroll 1983; Schroll 1997, Schreiner 2007 adapted)
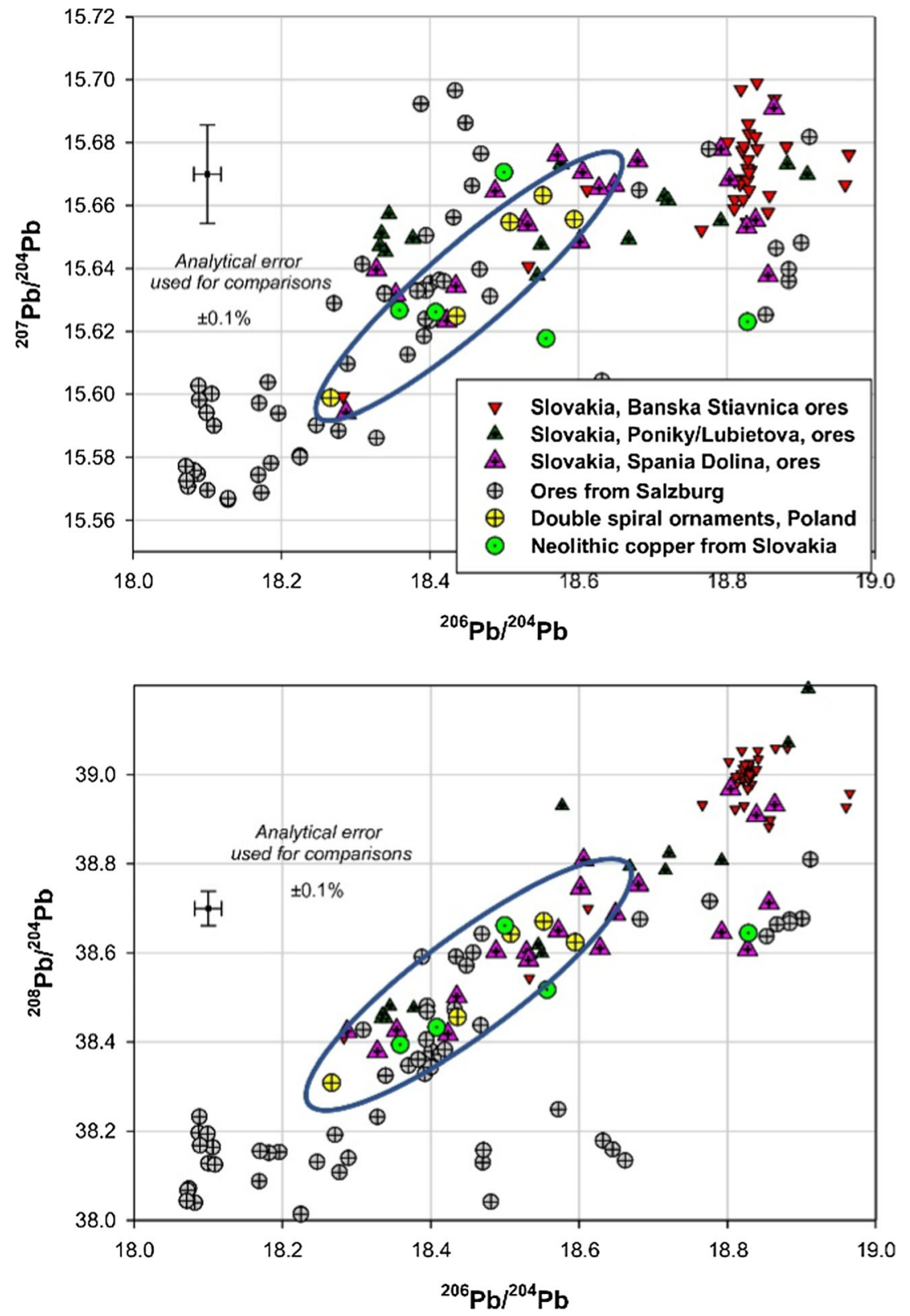
Fig. 7 Comparisons of lead isotope ratios to the radiogenic

${ }^{206} \mathrm{~Pb}$ of the analysed DSOs, the Neolithic/Eneolithic copper artefacts from Slovakia and ores from the Slovak Ore Mountains show that all their lead isotope ratios lie on a straight line within the analytical error, providing further evidence of their origin from the same ore deposit (Schreiner 2007, adapted)
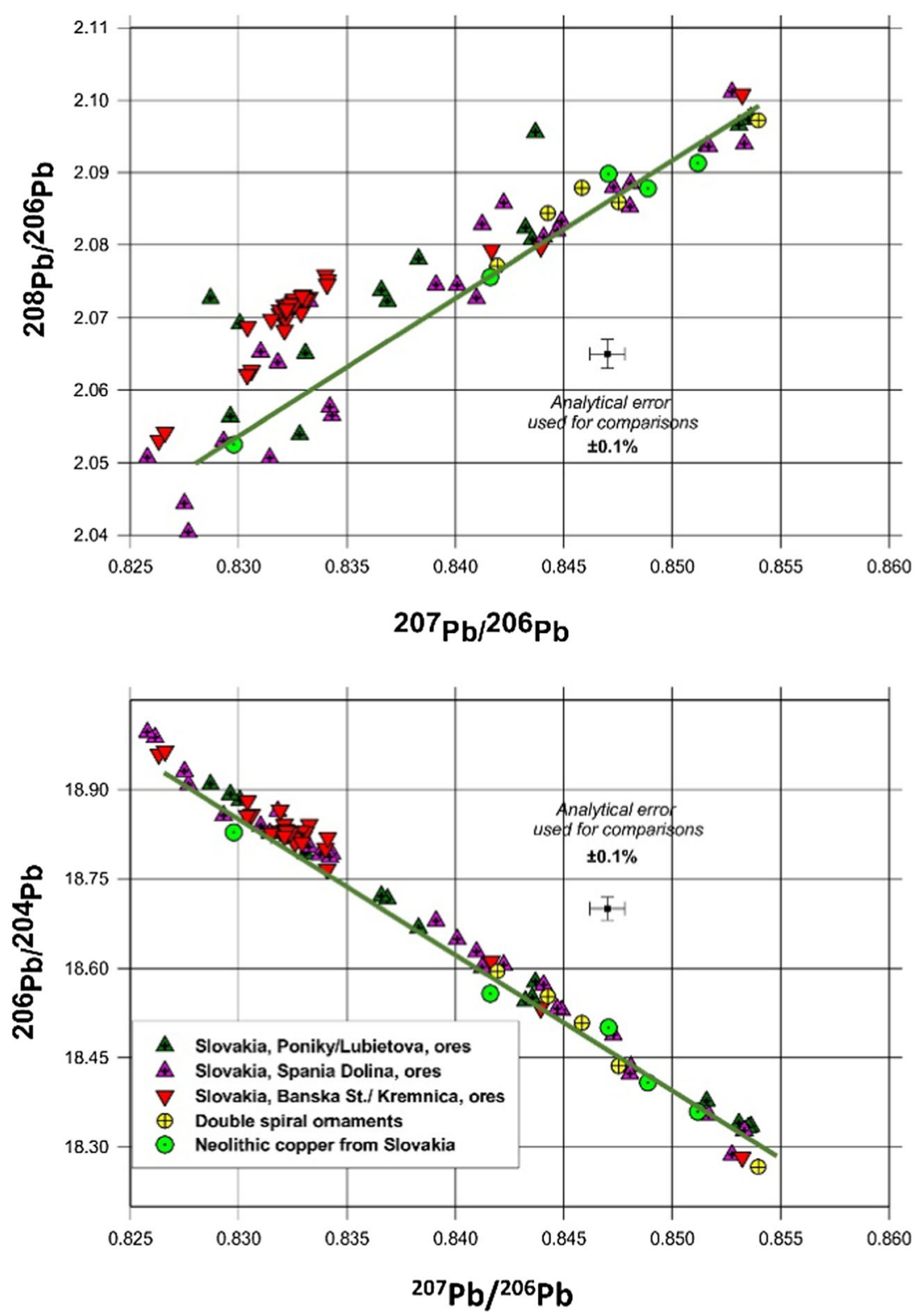
We sincerely hope that our unintentional oversight in referencing can be turned into a further step towards the integration of a wide archaeometallurgical audience that promotes cross-disciplinary dialogue and collegiality, allowing the researchers to trace and access the latest LIA results whilst keeping the atmosphere of friendship and kindness.

Reference (listed in order of the copper ore deposits)

\section{Austria:}

Köppel V (1983) Summary of lead isotope data from ore deposits of the Eastern and Southern Alps: Some metallogenetic and geotectonic implications. In: Schneider HJ (ed) Mineral Deposits of the Alps. Proc. IV ISMIDA 1981. Springer Verlag, Berlin Heidelberg, pp 162-168.

Köppel V, Schroll E (1983) Lead isotopes of Paleozoic, stratabound to stratiform galena bearing sulphide deposits of the Eastern Alps (Austria): implications for their geotectonic setting. Schweiz. Mineral Petrograph Mitt 63:347-360.

Schroll E (1997) Geochemische und geochronologische Daten und Erläuterungen. In: Weber L (ed) Handbuch der Lagerstätten der Erze, Industrieminerale und Energierohstoffe Österreichs. Arch. f. Lagerstättenforschung. Geol. B.-A., 19, pp 395-538.

\section{Cyprus:}

Gale NH, Stos-Gale ZA, Maliotis G, Annetts N (1997) Lead isotope data from the Isotrace Laboratory, Oxford: Archaeometry data base 4, ores from Cyprus. Archaeometry 39(1):237-246.

OXALID : http://oxalid.arch.ox.ac.uk.

\section{Harz Mountains:}

Bielicki K-H, Tischendorf G (1991) Lead isotope and Pb- Pb model age determinations of ores from Central Europe and their metallogenetic interpretation. Contrib Mineral Petr 106:440-461.

Haak U, Lévêque L (1995) Bleiisotope: Anwendung in Lagerstättenkunde, Archäometrie und Umweltforschung am Beispiel des Harzes. Mitt Österr Miner Ges 140:131-141.

Niederschlag E, Pernicka E, Seifert T, Bartelheim M (2003) The determination of lead isotope ratios by multiple collector Icp-Ms: A case study of early Bronze age artefacts and their possible relation with ore deposits of the Erzgebirge. Archaeometry 45(1):61-100.
Tischendorf G, Bielicki KH, Franzke HJ (1993) On the genesis of Permian and Post-Permian hydrothermal mineralizations in the Harz Mountains according to new $\mathrm{Pb}$ Isotope measurements. Monogr Ser Mineral Deposita 30:65-76.

\section{Massif Central:}

Baron S, Carignan J, Laurent S, Ploquin A (2006) Medieaval lead making on Mont-Lozere Massif (Cévennes-France): Tracing ore sources using $\mathrm{Pb}$ isotopes. Appl Geochem 21:241-252.

Brevart O, Dupre B, Allegre CJ (1982) Metallogenic provinces and the remobilisation process studies by lead isotopes; lead-zinc ore deposits from the southern Massif Central, France. Econ Geol 77(3):564-575

Le Guen M, Lancelot JR (1989) Origine du Pb-Zn des minéralisations du Bathonien sud-cévenol: apport de la géochimie isotopique comparée des galènes, de leur encaissant et du socle. Chron Rech Min 495:31-36.

Le Guen M, Orgeval J-J, Lancelot J (1991) Lead isotope behaviour in a polyphased $\mathrm{Pb}-\mathrm{Zn}$ ore deposit: Les Malines (Cévennes-France). Miner Deposita 26(3):180-188.

Marcoux E, Brill H (1986) Héritage et sources des métaux d'après la géochimie isotopique du plomb. Miner Deposita 21:35-43.

Sinclair AJ, Macquar JC, Rouvier H (1993) Re-evaluation of lead isotopic data, southern Massif Central, France. Miner Deposita 28(2):122-128.

\section{Slovakia:}

Andras P, Chovan M, Dirner V, Kral J, Bachlinski R (2010) $\mathrm{Pb}$-isotope study in Sb-mineralisation from Western Carpathian (Slovakia). Carpath J Earth Env 5(2):71-80.

Chernyshev IV, Chagaev AV, Shatagin KN (2007) High precision $\mathrm{Pb}$ isotope analysis by Multicollector-ICPMass Spectrometry using 205T1/203Tl normalisation: Optimisation and calibration of the method for the studies of $\mathrm{Pb}$ isotope variation. Geochem Int+ 45(11):10651076.

Schreiner M (2007) Erzlagerstätten im Hrontal, Slowakei: Genese und prähistorische Nutzung (= Forschungen zur Archäometrie und Altertumswissenschaft, Band 3). Verlag Marie Leidorf Gmbh., Rahden/Westf. 


\section{South-West Spain:}

Arribas A jr, Tosdal RM (1994) Isotopic composition of Pb in ore deposits of the Betic Cordillera, Spain: origin and relationship to other European deposits. Econ Geol 89:1074-93.

Hunt-Ortiz MA (2003) Prehistoric Mining and Metallurgy in South-West Iberian Peninsula. BAR International Series 1188:349-370.

Klein S, Domergue C, Lahaye Y, Brey GP, Von Kaenel H-M (2009) The lead and copper isotopic composition of copper ores from the Sierra Morena (Spain). J Iber Geol 35(1):59-68.

OXALID: http://oxalid.arch.ox.ac.uk.

Renzi M, Montero-Ruiz I, Bode M (2009) Non-ferrous metallurgy from the Phoenician site of La Fonteta (Alicante, Spain): a study of provenance. J Archaeol Sci 36:2584-2596.

Santos Zaldeuegui JF, Garcia de Madinabeitia S, Gil Ibarguchi JI, Palero F (2004) A lead isotope database: The Los Pedroches Alcudia area (Spain); Implications for archaeometallurgical connections across south western and southeastern Iberia. Archaeometry 46(4):625-634.

Stos-Gale ZA, Gale NH, Houghton J, Speakman R (1995) Lead isotope analyses of ores from the Western Mediterranean. Archaeometry 37(2):407-415.

Tornos F, Inverno CMC, Casquet C, Mateus A, Ortiz G, Oliveira V (2004) The metallogenic evolution of the OssaMorena Zone. J Iber Geol 30:143-181.

\section{Switzerland:}

Beck B (2019) Le travail du plomb a Sion, Sous-le-Scex. In: Haldimann, M-A, Paccolat O (eds) Sion, Sous le Sex (Valais, Suisse), III. Développement d'un quartier de la ville antique. Archeologia Vallesiana 16, CAR 178, Lausanne, pp 83-96.

Cattin F, Guénette-Beck B, Curdy P, Meisser N, Ansermet S, Hofmann B, Kündig R, Hubert V, Wörle M, Hametner K, Günther D, Wichser A, Ulrich A, Villa IM, Besse M (2011) Provenance of Early Bronze Age Metal Artefacts in Western Switzerland using elemental and lead isotopic compositions and their possible relation with copper minerals of the Nearby Valais. J Archaeol Sci 38(6):1165-1394.

Additional references for published lead isotope data can be found in:

Cattin F, Guénette-Beck B, Besse M, Serneels V (2009) Editorial. In: Proc. workshop lead isotopes and archaeometallurgy (June 19-20 2008; Fribourg, Switzerland). Archaeol Anthropol Sci 1:137-148.

Melheim L, Grandin L, Persson P.-O, Billström K, Stos-Gale Z, Ling J, Williams A, Angelini I, Canovaro C, Hjärthner-Holdar E, Kristiansen K (2018) Moving metals III: Possible origins for copper in bronze Age Denmark based on lead isotopes and geochemistry. J Archaeol Sci 96: 85-105.

Publisher's note Springer Nature remains neutral with regard to jurisdictional claims in published maps and institutional affiliations. 